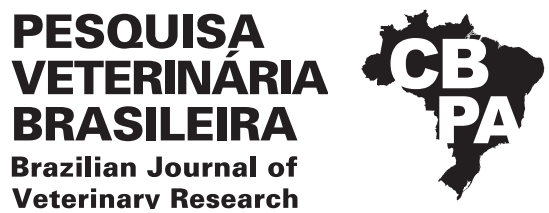

Pesq. Vet. Bras. 40(11):898-902, November 2020 DOI: $10.1590 / 1678-5150-P V B-6730$

Original Article

inary Research

Small Animal Diseases

ISSN 0100-736X (Print)

ISSN 1678-5150 (Online)

\title{
Immunomodulatory effect of Bacillus toyonensis BCT- 7112 supplementation in puppies vaccinated against canine parvovirus ${ }^{1}$
}

\begin{abstract}
Helen C. Franz ${ }^{2}$, Neida L. Conrad ${ }^{2}$, Francisco D.S. Santos ${ }^{2}$, Vitória S. Gonçalves ${ }^{2}$, Renata N. Fonseca ${ }^{2}$, Carolina L. Brasil ${ }^{2}$, Silvia de O. Hübner ${ }^{3}$ and Fábio P.L. Leite ${ }^{2 *}$ (D)

ABSTRACT.- Franz H.C., Conrad N.L., Santos F.D.S., Gonçalves V.S., Fonseca R.N., Brasil C.L., Hübner S.O. \& Leite F.L.P. 2020. Immunomodulatory effect of Bacillus toyonensis BCT-7112 supplementation in puppies vaccinated against canine parvovirus. Pesquisa Veterinária Brasileira 40(11):898-902. Núcleo de Biotecnologia, Centro de Desenvolvimento Tecnológico, Universidade Federal de Pelotas, Campus Capão do Leão, Pelotas, RS 96010-900, Brazil. E-mail: fleivasleite@gmail.com, fabio_leite@ufpel.edu.br

Bacillus toyonensis is a probiotic microorganism that for decades has been used in animal nutrition around the world. The objective of this work was to evaluate the immunomodulatory effect of oral B. toyonensis supplementation in dogs vaccinated against canine parvovirus. Puppies were randomly selected and divided in two groups, one received $B$. toyonensis at a concentration of $2 \times 10^{8}$ viable spores per day and another group without supplementation was left as control. The puppies were vaccinated against canine parvovirus type 2. B. toyonensis supplementation was efficient in stimulating specific IgG for parvovirus with titers of 2,3 , and 2.5 -fold higher than controls at 7, 21, and 35 pos-vaccination days respectively. Peripheral blood mononuclear cells (PBMCs) from dogs were cultured and stimulated with $B$. toyonensis DNA, vegetative cell and spores. The mRNA transcription of cytokines IL-4, IL-17, and IFN- $\gamma$ up modulated by the stimuli. Thus, we conclude in this study that $B$. toyonensis supplementation may amplify the vaccine immune response against canine parvovirus.
\end{abstract}

INDEX TERMS: Immunomodulatory effect, Bacillus toyonensis, BCT-7112, supplementation, puppies, vaccine, canine parvovirus, probiotic, adjuvancity, dogs.

RESUMO.- [Efeito imunomodulador da suplementação de Bacillus toyonensis BCT-7112 em cachorros vacinados contra o parvovírus canino.] Bacillus toyonensis é um micro-organismo probiótico que há décadas é utilizado na nutrição animal em todo o mundo. 0 objetivo deste trabalho foi avaliar o efeito imunomodulador da suplementação oral de $B$. toyonensis em cães vacinados contra o parvovírus canino. Os filhotes foram selecionados aleatoriamente e divididos em dois grupos, um recebeu $B$. toyonensis na concentração de $2 \times 10^{8}$ esporos viáveis por dia e outro grupo sem suplementação como controle. Os filhotes foram vacinados contra o parvovírus canino tipo 2 . A suplementação

\footnotetext{
${ }^{1}$ Received on August 18, 2020.

Accepted for publication on September 1, 2020.

${ }^{2}$ Núcleo de Biotecnologia, Centro de Desenvolvimento Tecnológico, Universidade Federal de Pelotas (UFPel), Campus Capão do Leão, Pelotas, RS 96010-900, Brazil. *Corresponding author: fleivasleite@gmail.com, fabio_leite@ufpel.edu.br

${ }^{3}$ Laboratório de Virologia, Faculdade de Veterinária, Universidade Federal de Pelotas (UFPel), Campus Capão do Leão, Pelotas, RS 96010-900, Brazil.
}

com B. toyonensis foi eficiente em estimular IgG específica para parvovírus com títulos de 2, 3 e 2,5 vezes maior que os controles aos 7, 21 e 35 dias pós-vacinação, respectivamente. Células mononucleares do sangue periférico (PBMCs) de cães foram cultivadas e estimuladas com DNA de B. toyonensis, células vegetativas e esporos. A transcrição do mRNA das citocinas IL-4, IL-17 e IFN- $\gamma$ foi modulada pelos estímulos. Assim, concluímos neste estudo que a suplementação com B. toyonensis pode amplificar a resposta imune da vacina contra o parvovírus canino.

TERMOS DE INDEXAÇÃO: Efeito imunomodulador, suplementação, Bacillus toyonensis, BCT-7112, cachorros, vacina, parvovírus canino, probiótico, adjuvanticidade, caninos.

\section{INTRODUCTION}

Vaccination of dogs has been regarded as one of the major success interventions in veterinary medicine and has proven successful by preventing future infections. Vaccination stimulates both humoral and cellular response (Greene et al. 2001), been 
the duration of immunity depends on the immunological memory established (Pardo et al. 1997, Tizard 2004). Puppies can vary its ability to respond to vaccines, been the principal cause, levels of persistent maternal immunity. The first prime immune response to the vaccine antigen needs to be effective in order to subsequent exposures to the same antigen eliciting a stronger and faster response (Davis-Wurzler 2006). One possible way to improve vaccine initial prime immune response is by modulating the immune system with the supplementation of probiotics (Roos et al. 2010, 2012, 2018, Santos et al. 2018).

Probiotics are microorganisms that are added to the diet to exert beneficial effects on the host. Probiotics have the potential to stimulate innate immune responses without inducing inflammation; initiate responses mediated by interacting with follicle-associated epithelial cells, macrophages, T- and B-lymphocytes and dendritic cells (DCs) (Matsumoto et al. 2011). DCs activated by probiotic, stimulate naïve $T$ lymphocytes, which migrate to the mesenteric lymph nodes, then systemic circulation where they can mount an immune response far from the location of their original activation (Lebeer et al. 2010).

Bacillus toyonensis is a non-pathogenic Gram-positive bacterium that has been used as a probiotic in animal feed (Gil-Turnes et al. 2007, Williams et al. 2009). Supplementation with $B$. toyonensis exerts immunomodulatory effects capable of enhancing the effectiveness of vaccines in sheep, pigs and mice (Coppola et al. 2005, Roos et al. 2010, 2012).

Canine parvovirus (CPV) is an important enteric pathogen because of the associated high morbidity and mortality rates (Greene 2012). CPV, caused by three variants of canine parvovirus type 2 (CPV-2; family Parvoviridae, genus Parvovirus), is a leading cause of morbidity and mortality in dogs globally. CPV-2 evolved into two variants (CPV-2a and CPV-2b) (Carmichael 2005, Martella et al. 2006) while in 2000, a third variant (CPV-2c) has been reported (Buonavoglia et al. 2001, Decaro et al. 2006). It can affect dogs of any age, but severe infections are most likely to occur from 6 weeks to 6 months after birth (Miranda \& Thompson 2016). Vaccination has proven successful to prevent CPV infections (Thiry \& Horzinek 2007, Greene \& Vandevelde 2012). Current recommendations suggest that puppies should have the first (or primary) vaccination scheduled between the first 6 and 8 weeks of age, followed by a booster shot. The number of vaccine boosts required might vary with the vaccination protocol, but principally with the prime vaccine effective response (Day et al. 2016).

Thus, the main goal of this study was to investigate the $B$. toyonensis immune modulation in puppies undergoing CPV vaccination.

\section{MATERIALS AND METHODS}

Probiotics. The probiotic used in this study, Bacillus toyonensis BCT-7112 $2^{\mathrm{T}}$, was sourced from the "Laboratório de Microbiologia", "CDTec-Núcleo de Biotecnologia”, "Universidade Federal de Pelotas" (UFPel), Brazil. B. toyonensis preparations were made as previously described by Santos et al. (2018). Briefly, the bacteria were cultured in a bioreactor (BIOSTAT ${ }^{\circledR}$ B; Braun Biotech International, Melsungen, Germany) containing 3.5 L of Nutrient Yeast Extract Salt medium (NYSM; $0.5 \%$ meat peptone, $0.5 \%$ meat extract, $0.1 \%$ yeast extract, $0.5 \mathrm{mM} \mathrm{KH}_{2} \mathrm{PO}_{4}, 0.8 \mathrm{mM} \mathrm{MgSO}_{4}, 0.06 \mathrm{mM} \mathrm{MnSO}_{4}, 0.06 \mathrm{mM} \mathrm{ZnSO}_{4}$, $0.06 \mathrm{mM} \mathrm{FeSO}_{4}, 0.01 \mathrm{mM} \mathrm{CaCO}_{3}$ ), maintained under shaking, at $37^{\circ} \mathrm{C}$ for $96 \mathrm{~h}$. The resultant culture was spun down in a Sorvall ${ }^{\mathrm{TM}}$ RC 6 Plus centrifuge (Thermo Scientific, Langenselbold, Germany) at $5,000 \times g$, for $20 \mathrm{~min}$, at $4^{\circ} \mathrm{C}$ and the pellet was resuspended in $500 \mathrm{ml}$ of phosphate buffered saline (PBS; $137 \mathrm{mM}$ sodium chloride, $10 \mathrm{mM}$ sodium phosphate, $2.7 \mathrm{mM}$ potassium chloride; $\mathrm{pH} 7.4$ ). Gram staining and culturing in sheep blood agar were used to ensure the purity of the strains at all stages of culture.

Ethical standards. All dogs were maintained and handled at the owner house, with no food or water restrictions. All procedures were performed in accordance with the Brazilian Committee for animal care and use (COBEA) guidelines and were approved by the UFPel Ethics Committee for animal research (project number 3246)

Supplementation and vaccination of the dogs. Ten Australian Cattle Dog, seven males and 3 females, 11 weeks old, were randomly divided in two groups, 5 animals each, supplemented and control. The supplemented group received $2 \times 10^{8} \mathrm{~B}$. toyonensis viable spores (on $1 \mathrm{ml}$ ) orally once a day, whereas the control group received $1 \mathrm{ml}$ of PBS. The probiotic supplementation starts 7 days prior the prime vaccination and was maintained until the end of the experimental period (day 35). The vaccination follows the owner protocol, using two shots of Vanguard ${ }^{\circledR}$ HTLP 5/CV-L ${ }^{4}$ with a 21-day interval, days 7 and 28 of the experimental period. Whole blood was collected on day $0,7,21$ e 35 using a standard jugular venipuncture approach and evacuated into sterile tubes containing ethylenediaminetetraacetic acid (EDTA) as an anticoagulant.

Clinical and hematological parameters. All dogs were monitored to respiratory and cardiac rate, body temperature during all experiment. Hematological parameters including red blood cells (RBCs) and white blood cells (WBCs) count and hemoglobin concentration $(\mathrm{Hb})$ were analyzed using a PocH - 100iVDiff ${ }^{\circledR} 5$. Blood smears were immediately prepared from EDTA blood samples and were stained with Diff Quick stain (EMD Chemicals Inc., Gibbstown/ New Jersey 08027, USA) and 200 leukocytes were differentiated in smears prepared from each animal.

Canine parvovirus antigen. The strain Cornell of canine parvovirus, used as antigen in ELISA, was kindly supplied by the "Laboratório de Virologia e Imunologia Veterinária" of the "Faculdade de Veterinária" of UFPel. The virus was inoculated in CRFK cells (Crandell feline kidney cells ATCC ${ }^{\circledR}$ CCL- $94^{\mathrm{TM}}$ ) maintained in minimal essential media (MEM, Sigma-Aldrich, St. Louis/MO, USA at $37^{\circ} \mathrm{C}$, until observation of cytophatic effect on $90 \%$ of cells ( $\sim 72$ hours). The virus suspension was titrated by hemagglutination using porcine erythrocytes according to (Pratelli et al. 2001). The titer of the virus was adjusted for 128 hemagglutinating units (UHA).

Indirect ELISA. The estimation of total specific IgG levels was carried out by indirect ELISA. Briefly, 96-well microplates (Corning ${ }^{\circledR}$, New York, USA) were coated with $50 \mu$ l per well of CPV suspension containing 128 UHA diluted in coating buffer $(0.1 \mathrm{M}$ carbonate bicarbonate buffer, $\mathrm{pH} 9.6$ ) at $4^{\circ} \mathrm{C}$ overnight. The response throughout the experiment was verified by analyzing the sera collected on days 0, 7, 21 and 35, diluted 1:1000 in PBS-T. To determine the antibody titer serum samples were serially two-fold diluted starting at 1:100 to $1: 51200$ and added to the plates in triplicate. After incubation at $37^{\circ} \mathrm{C}$ for $60 \mathrm{~min}$, the plates were washed three times with PBS-T, followed by addition of $100 \mu \mathrm{l}$ of horseradish peroxidase (HRP)conjugated rabbit anti-dog IgG whole molecule antibodies (1:4000 dilution, Sigma-Aldrich, St. Louis/MO, USA). Finally, $100 \mu$ l of substrate solution $(10 \mathrm{mg}$ ortho-phenylenodiamine (OPD, Sigma-Aldrich) in $10 \mathrm{ml}$ of $0.1 \mathrm{M}$ phosphate citrate buffer and $10 \mu \mathrm{l}$ of $30 \% \mathrm{H}_{2} \mathrm{O}_{2}$ ) was added to each well and the plates were incubated in the dark at 
room temperature for $15 \mathrm{~min}$. Further, $50 \mu \mathrm{l}$ of $2 \mathrm{~N} \mathrm{H}_{2} \mathrm{SO}_{4}$ was added to each well to stop the reaction.

Culture of peripheral blood mononuclear cells and RNA extraction. Blood was collected from healthy adult dogs and Peripheral Blood Mononuclear Cells (PBMCs) isolated as previously described by Leite et al. (2004). Approximately $5 \times 10^{7}$ cells were cultured in 24-well plates (Kasvi, China) containing $1 \mathrm{ml}$ of RPMI 1640 medium (Gibco, USA) with 10\% fetal bovine serum (FBS; Gibco), 10,000IU/ml penicillin, 10mg/ml streptomycin, and 25mg/ $\mathrm{ml}$ amphotericin $\mathrm{B}$ (Gibco) for $24 \mathrm{~h}$ at $37^{\circ} \mathrm{C}$ in $5 \% \mathrm{CO}_{2}$ atmosphere. PBMCs were stimulated with $B$. toyonensis DNA $(5 \mu \mathrm{g})$; vegetative cells $\left(10^{6}\right.$ UFC) and spores $\left(10^{6}\right.$ UFC). Were also stimulated with $10 \mu \mathrm{g}$ of concanavalin A (ConA) (Sigma-Aldrich) as a positive control, whereas RPMI 1640 as a negative control. The plates were incubated for $18 \mathrm{~h}$ under the same conditions. The supernatants were then discarded, and the cells were resuspended in TRIzol ${ }^{\circledR}$ Reagent (Life Technologies, Carlsbad/CA, USA) for RNA extraction following the manufacturer's instructions.

cDNA synthesis and qPCR. Reverse transcription was carried out using High Capacity cDNA Reverse Transcription Kit (Applied Biosystems, Foster City, USA) using approximately 400 ng of RNA. Relative mRNA expression levels for interleukin (IL)-4, interleukin (IL)-17 and interferon (IFN)- $\gamma$ were determined using quantitative polymerase chain reaction (qPCR) with $\beta$-actin and GAPDH used as endogenous reference genes (controls); $\beta$-actin was standardized as an internal reference gene based on its efficiency (M-value of 1.98). qPCR reactions were performed on a Stratagene Mx3005P qPCR system (Agilent Technologies, Santa Clara, USA), as described previously (De Avila et al. 2016). The primers used were described elsewhere (Hassanpour et al. 2017). All samples were analyzed in triplicate using the comparative threshold cycle $\left(2^{-\Delta \Delta \mathrm{ct}}\right)$ method to determine the relative mRNA expression compared to $\beta$-actin as the reference gene. The Ct values obtained by the qPCR were analyzed using the following equation (Livak \& Schmitted 2001): $\Delta \Delta \mathrm{Ct}=$ (CtTarget-CtHousekeping)-(CtTarget-CtHousekeping).

Statistical analysis. The data were analyzed using GraphPad Prism version 7 (USA). The differences in antibody titers between groups were analyzed using ELISA values, where positive were considered values of $+3 \mathrm{SD}$ above the mean of the negative controls. The results were subjected to two-way analysis of variance (ANOVA) followed by Tukey's Multiple Comparisons test. A one-way ANOVA followed by Dunnett's test was used to analyze differences between cytokine mRNA transcription.

\section{RESULTS}

No significant difference was detected in the respiratory rate, pulse rate, body temperature between groups. Also, the hematological parameters were the expected for the dogs age. These results suggest that the Bacillus toyonensis supplementation did not cause any observable adverse physiological effects to the dogs and that it was safe for use in dogs.

All animals of experimental groups had similar maternal antibody levels against CPV on day 0 of the experiment. Total specific IgG levels were increased in both groups in response to vaccination. Significantly higher IgG titers were observed for B. toyonensis supplemented dogs $(\mathrm{P}<0.05)$ as compared with the control group. At seven days after the primer immunization, the supplemented group had significant $(\mathrm{P}<0.05)$ high levels of specific total IgG anti-CPV comparing with the control group (Fig.1A). Noteworthy, that the IgG levels in the supplemented group continue increasing, on day 21 there was, almost 3 -fold increase comparing with the control group. After the boost, the both groups responded following the same trend (Fig.1A). At day 35 of the experiment, the levels of specific IgG in the supplemented group also were significantly higher than the control group reaching up to 1:51200, 8-fold higher than the controls (Fig.1B).

In order to evaluate the cytokines mRNA transcription of PBMCs stimulated with $B$. toyonensis, PBMCs from healthy adult dogs were stimulated with $B$. toyonensis DNA, vegetative cells and spores. PBMCs stimulated with $B$. toyonensis DNA were able to induce significant transcription levels of IL-4 by 4.7, IL-17 by 3.5 , and IFN- $\gamma$ by 2 -fold (Fig. 2A). Stimulus with vegetative cells showed an increase transcription level for IL-4, IL-17 and IFN- $\gamma$ of 1.7, 3.15 and 1.2-fold, respectively (Fig.2B). Then, when stimulated with $B$. toyonensis spores had an increase in cytokines transcription levels of 4.4, 1.3, and 1.6-fold, for IL-4, IL-17 and IFN- $\gamma$ respectively (Fig.2C).

\section{DISCUSSION}

Vaccination is the most effective and cost-benefice method of controlling infectious diseases in domestic animals (Loots et al. 2017, Thiry \& Horzinek 2007). Vaccine efficacy can be measure by the ability to induce specific serum antibody against the pathogen. The level of specific antibodies elicited
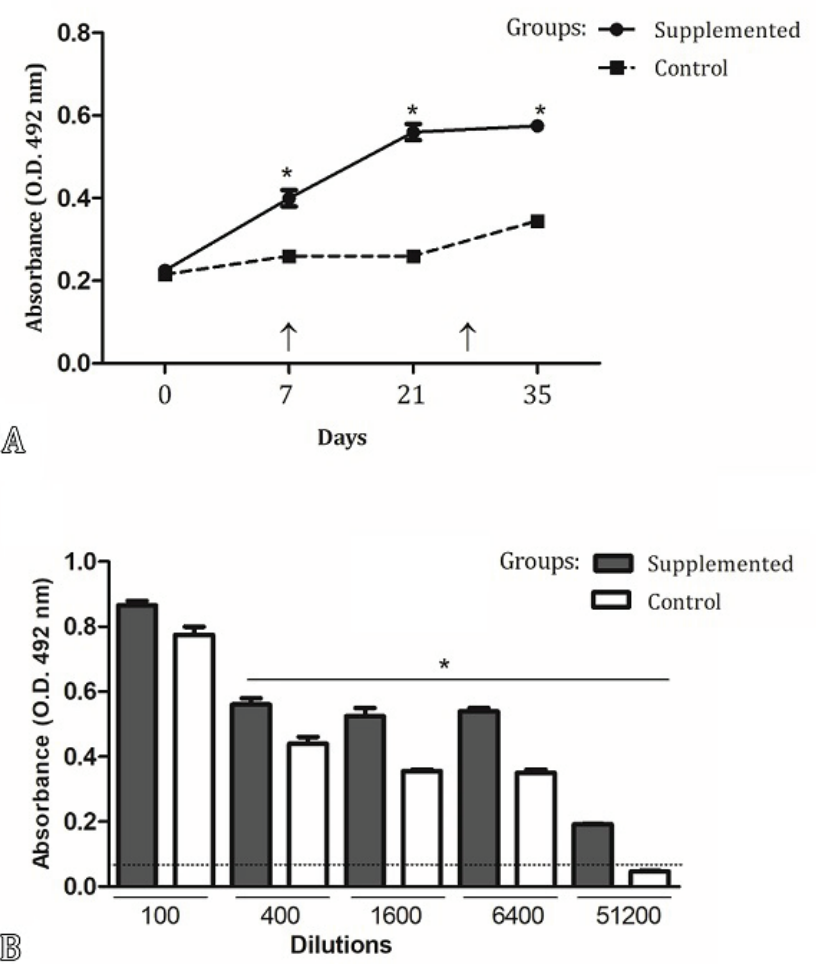

Fig.1. Dynamics of total IgG against canine parvovirus. The data represent the mean of ELISA values of specific total IgG against canine parvovirus (CPV) in the Bacillus toyonensis supplemented and control dogs. (A) Antibody response in different time points of the experiment. Arrows indicate vaccination days. (B) Specific CPV serum IgG titer of vaccinated dogs at 35 th day of experiment. The dotted line represents the cut-off (the mean of the negatives $+3 \mathrm{SD})$. Asterisks mean significant difference $(\mathrm{P}<0.05)$ between the $B$. toyonensis supplemented and control group. 

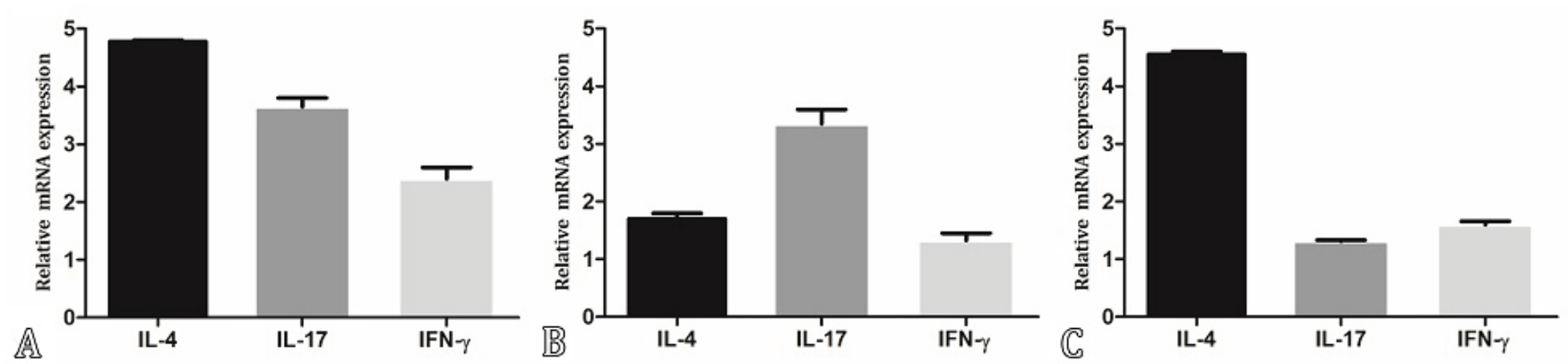

Fig.2. Quantitative polymerase chain reaction (qPCR) of cytokine mRNA transcription for IL-4, IL-17, and IFN-y. The data represent the mean ( \pm standard error) of cytokine mRNA transcription of canine PBMCs stimulated with Bacillus toyonensis (A) DNA; (B) vegetative cells and (C) spores. The relative mRNA expression was determined by the comparative threshold cycle $\left(2^{-\Delta \Delta C}\right)$.

by a vaccine against CPV usually correlates with protection (Jensen et al. 2015). Consequently, studying vaccine antibody responses in animals supplemented with probiotic one may consider a good way to determine the probiotics modulation of the immune responses to $\mathrm{CPV}$.

In this study, we observed that dogs vaccinated and supplemented with $B$. toyonensis, presented significant higher specific anti-CPV IgG levels when compared to with the control group (Fig.1). Remarkable, the significant higher levels of specific CPV IgG antibodies in supplemented dogs were developed after prime vaccination, with an increase of approximately 2 and 3-folds at 7 and 21 days, respectively, comparing with the control group. After the boost (day 28), although both groups responded, the control group do not reach the IgG levels of the supplemented group, showing a level of antibodies significantly lower than the supplemented group. These findings are quite interesting, since one can assume that the maturity of immune system, as well as, the level of maternal antibodies of the dogs were similar, suggesting that the $B$. toyonensis immune modulation was the responsible to induce higher levels of antibodies anti-CPV.

One mechanism of probiotic immune modulation is by change the cytokine profile produced in the environment where the vaccine antigens will interact with the immune cells (Shida et al. 2011). The higher levels of IL-4, IL-17 and IFN- $\gamma$ mRNA transcription observed when PBMCs were stimulated with $B$. toyonensis (DNA, vegetative cell and spore), suggest that these cytokines might play a role in the $B$. toyonensis modulation of vaccine response to CPV (Roos et al. 2012, Santos et al. 2018).

We observed an up regulation for IL-4, IL-17 and IFN-y mRNA transcription on PBMCs $(\mathrm{p}<0.05)$. The cytokine IL-4 is mainly produced by Th2 lymphocytes and promotes B lymphocyte response and isotype switching (Paul \& Zhu 2010). The presence of IL-4 improves antigen presentation through increased expression of major histocompatibility complex II molecules, maturation of DCs and T lymphocytes proliferation (Finkelman et al. 1990, Lutz et al. 1996, Wells et al. 2005). Interleukin-17 (IL-17) is a pro-inflammatory cytokine produced by a subset of T helper cells (Th17). These cells act as physiological mediators of inflammation and are characterized by a unique expression pattern of transcription factors and cytokines. It was demonstrated that IL-17 not only trigger B-lymphocyte proliferation, but also promote the formation of GCs (Germinal Centers) together with IgG isotype switching (Mitsdoerffera et al. 2010). Our experiment revealed an increase IL-17 mRNA transcription on PBMCs with different B. toyonensis stimuli, compared with control group. The significant higher levels of IFN-y mRNA transcription observed on canine PBMCs suggest the stimulation of a Th1 response, an effect of great importance on the vaccine immune response, principally for anti-viral vaccines. Previously, it was reported a similar effect on IFN-y mRNA transcription in mice supplemented with B. toyonensis and vaccinated against BoHV-5 (Roos et al. 2012, Santos et al. 2018). The increase in mRNA transcription of the cytokines IL-4, IL-17, and IFN- $\gamma$ due probiotic modulation may have resulted in significantly greater levels of total specific CPV IgG, as detected in the sera of the probiotic-supplemented animals. Therefore, it is possible to suggest that part of the probiotic immune modulation effect on the antibody dynamics, observed in this study, may be due to the cytokines.

\section{CONCLUSION}

The data obtained in this study allow us to conclude that the supplementation of dogs with Bacillus toyonensis have a modulatory effect on immune response against canine parvovirus vaccine.

Acknowledgements.- We would like to thank to Dra. Luciana Bicca Dode and DVM Maria Eduarda Bicca Dode for providing and taking care of the dogs. We would also thank to "Coordenação de Aperfeiçoamento de Pessoal de Nível Superior" (CAPES), Brazil, Finance Code 001, and "Conselho Nacional de Desenvolvimento Científico e Tecnológico" (CNPq) for scholarships.

Conflict of interest statement.- The authors report no conflicts of interest.

\section{REFERENCES}

Buonavoglia C., Martella V., Pratelli A., Tempesta M., Cavalli A., Buonavoglia D. \& Carmichael L. 2001. Evidence for evolution of canine parvovirus type 2 in Italy. J. Gen. Virol. 82(Pt12):3021-3025. <https://dx.doi.org/10.1099/00221317-82-12-3021><PMid:11714979>

Carmichael L.E. 2005. An annotated historical account of canine parvovirus. J. Vet. Med. B 52(7/8):303-311.<https://dx.doi.org/10.1111/j.1439-0450.2005.00868.x> $<$ PMid:16316389>

Coppola M.D.M., Conceição F.R. \& Gil-Turnes C. 2005. Effect of Saccharomyces boulardii and Bacillus cereus var. toyoi on the humoral and cellular response of mice to vaccines. Food Agr. Immunol. 16(3):213-219. <https://dx.doi. org/10.1080/09540100500244138>

Davis-Wurzler G.M. 2006. Current vaccination strategies in puppies and kittens. Vet. Clin. N. Am., Small Anim. Pract. 36(3):607-640. <https://dx.doi.org/10.1016/j.cvsm.2013.11.006> <PMid:24580989> 
Day M.J., Horzinek M.C., Schultz R.D. \& Squires R.A. 2016. Guidelines for the vaccination of dogs and cats compiled by the Vaccination Guidelines Group (VGG) of the World Small Animal Veterinary Association (WSAVA). J. Small Anim. Pract. 57:E1-E45.

De Avila L.D.C., De Leon P.M.M., De Moura M.Q., Berne M.E.A., Scaini C.J. \& Leivas Leite F.P. 2016. Modulation of IL-12 and IFN $\gamma$ by probiotic supplementation promotes protection against Toxocara canis infection in mice. Parasite immunol. 38(5):326-330. <https://dx.doi.org/10.1111/ pim.12314 > <PMid:26971490>

Decaro N., Martella V., Desario C., Bellacicco A. L., Camero M., Manna L. \& Buonavoglia C. 2006. First detection of canine parvovirus type 2c in pups with haemorrhagic enteritis in Spain. J. Vet. Med. B 53(10):468-472. <https://dx.doi.org/10.1111/j.1439-0450.2006.00974.x><PMid:17123424>

Finkelman F.D., Holmes J., Katona I.M., Urban Jr J.F., Beckmann M.P., Park L.S. \& Paul W.E. 1990. Lymphokine control of in vivo immunoglobulin isotype selection. Annu. Rev. Immunol. 8:303-333.<https://dx.doi.org/10.1146/ annurev.iy.08.040190.001511><PMid:1693082>

Gil-Turnes C., Conceição F.R. \& De Los Santos J.G. 2007. Bacillus cereus var. toyoi improves feed efficiency and health in animals. I. J. Probiotics Prebiotics 2(1):21-28.

Greene C.E. \& Vandevelde M. 2012. Canine distemper, p.25-42. In: Sykes J. \& Greene C.E. (Eds), Infectious Diseases of the Dog and Cat. 4th ed. Elsevier Saunders, St Louis.

Greene C.E. 2012. Feline enteric viral infections, p.80-91. In: In: Sykes J. \& Greene C.E. (Eds), Infectious Diseases of the Dog and Cat. 4th ed. Elsevier Saunders, St Louis.

Greene C.E., Schultz R.D. \& Ford R.B. 2001. Canine vaccination. Vet. Clin. N. Am., Small Anim. Pract. 31(3):473-492. <https://dx.doi.org/10.1016/ s0195-5616(01)50603-8><PMid:11446099>

Hassanpour H., Sadegh A.B., Karimi I., Khoei H.H., Karimi A., Shaarbaf P.E. \& Shayan T.K. 2017. Comparative expression analysis of HSP70, HSP90, IL-4, TNF, KITLG and KIT-receptor gene between varicocele-induced and non-varicocele testes of dog. Int. J. Fertil. Steril. 11(3):148-155. <https://dx.doi.org/10.22074/ijfs.2017.5020><PMid:28868836>

Jensen W.A., Totten J.S., Lappin M.R. \& Schultz R.D. 2015. Use of serologic tests to predict resistance to Canine distemper virus-induced disease in vaccinated dogs. J. Vet. Diagn. Invest. 27(5):576-580. <https://dx.doi. org/10.1177/1040638715602291><PMid:26330396>

Lebeer S., Vanderleyden J. \& De Keersmaecker S.C. 2010. Host interactions of probiotic bacterial surface molecules: comparison with commensals and pathogens. Natl Rev. Microbiol. 8(3):171-184.<https://dx.doi.org/10.1038/ nrmicro2297><PMid:20157338>

Leite F., Kuckleburg C., Atapattu D., Schultz R. \& Czuprynski C.J. 2004. BHV-1 infection and inflammatory cytokines amplify the interaction of Mannheimia haemolytica leukotoxin with bovine peripheral blood mononuclear cells in vitro. Vet. Immunol. Immunop. 99(3/4):193-202. <https://dx.doi. org/10.1016/j.vetimm.2004.02.004><PMid:15135985>

Livak K.J. \& Schmittgen T.D. 2001. Analysis of relative gene expression data using real-time quantitative PCR and the $2{ }^{-\Delta \Delta C}{ }_{T}$ method. Methods 25(4):402408. <https://dx.doi.org/10.1006/meth.2001.1262><PMid:11846609>

Loots A.K., Mitchell E., Dalton D.L., Kotzé A. \& Venter E.H. 2017. Advances in canine distemper virus pathogenesis research: a wildlife perspective. J. Gen. Vir. 98(3):311-321. <https://dx.doi.org/10.1099/jgv.0.000666> $<$ PMid:27902345>

Lutz M.B., Assmann C.U., Girolomoni G. \& Ricciardi-Castagnoli P. 1996. Different cytokines regulate antigen uptake and presentation of a precursor dendritic cell line. Eur. J. Immunol. 26(3):586-594. <https://dx.doi.org/10.1002/ eji.1830260313><PMid:8605925>

Martella V., Decaro N. \& Buonavoglia C. 2006. Evolution of CPV-2 and implicance for antigenic/genetic characterization. Virus genes 33(1):11-13. <https:// dx.doi.org/10.1007/s11262-005-0034-8><PMid:16791413>
Matsumoto M., Kurihara S., Kibe R., Ashida H. \& Benno Y. 2011. Longevity in mice is promoted by probiotic-induced suppression of colonic senescence dependent on upregulation of gut bacterial polyamine production. PloS One 6(8)e23652. <https://dx.doi.org/10.1371/journal.pone.0023652> $<$ PMid:21858192>

Miranda C. \& Thompson G. 2016. Canine parvovirus: the worldwide occurrence of antigenic variants. J. Gen. Vir. 97(9):2043-2057. <https:// dx.doi.org/10.1099/jgv.0.000540><PMid:27389721>

Mitsdoerffer M., Lee Y., Jäger A., Kim H.J., Korn T., Kolls J.K. \& Kuchroo V.K. 2010. Proinflammatory T helper type 17 cells are effective B-cell helpers. Proc. Natl Acad. Sci. 107(32):14292-14297. <https://dx.doi.org/10.1073/ pnas.1009234107>

Pardo M.C., Bauman J.E. \& Mackowiak M. 1997. Protection of dogs against canine distemper by vaccination with a canarypox virus recombinant expressing canine distemper virus fusion and hemagglutinin glycoproteins. Am. J. Vet. Res. 58(8):833-836. <PMid:9256965>

Paul W.E. \& Zhu J. 2010. How are TH 2-type immune responses initiated and amplified? Nat. Rev. Immunol. 10(4):225-235. <https://dx.doi.org/10.1038/ nri2735><PMid:20336151>

Pratelli A., Cavalli A., Martella V., Tempesta M., Decaro N., Carmichael L. E. \& Buonavoglia C. 2001. Canine parvovirus (CPV) vaccination: comparison of neutralizing antibody responses in pups after inoculation with CPV2 or CPV2b Modified Live Virus Vaccine. Clin. Diagn. Lab. Immunol. 8(3):612-615. <https://dx.doi.org/10.1128/CDLI.8.3.612-615.2001><PMid:11329467>

Roos T.B., de Moraes C.M., Sturbelle R. T., Dummer L.A., Fischer G. \& Leite F.P.L. 2018. Probiotics Bacillus toyonensis and Saccharomyces boulardii improve the vaccine immune response to Bovine herpesvirus type 5 in sheep. Res. Vet. Sci. 117:260-265. <https://dx.doi.org/10.1016/j.rvsc.2017.12.022> <PMid:29331687>

Roos T.B., Dummer L.A., Fischer G. \& Leite F.P.L. 2012. The immune modulation of Bacillus cereus var. Toyoi in mice immunized with experimental inactivated Bovine Herpesvirus Type 5 vaccine. Vaccine 30(12):2173-2177. <https:// dx.doi.org/10.1016/j.vaccine.2012.01.007> <PMid:22285271>

Roos T.B., Tabeleão V.C., Dümmer L.A., Schwegler E., Goulart M.A., Moura S.V. \& Gil-Turnes C. 2010. Effect of Bacillus cereus var. Toyoi and Saccharomyces boulardii on the immune response of sheep to vaccines. Food Agr. Immunol. 21(2):113-118. <https://dx.doi.org/10.1080/09540100903443691>

Santos F.D.S., Menegon Y.A., Piraine R.E.A., Rodrigues P.R.C., Cunha R.C. \& Leite F.P. 2018. Bacillus toyonensis improves immune response in the mice vaccinated with recombinant antigen of bovine herpesvirus type 5 . Benef. Microbes 9(1):133-142. <https://dx.doi.org/10.3920/BM2017.0021> <PMid:29022386>

Shida K., Nanno M. \& Nagata S. 2011. Flexible cytokine production by macrophages and $\mathrm{T}$ cells in response to probiotic bacteria: a possible mechanism by which probiotics exert multifunctional immune regulatory activities. Gut Microbes 2(2):109-114. <https://dx.doi.org/10.4161/ gmic.2.2.15661><PMid:21637028>

Thiry E. \& Horzinek M.C. 2007. Vaccination guidelines: a bridge between official requirements and the daily use of vaccines. Rev. Sci. Tech. 26(2):511517. <https://dx.doi.org/10.20506/rst.26.2.1758><PMid:17892170>

Tizard I.R. 2004. The use of vaccines, p.259-271. In: Ibid. (Ed.), Veterinary Immunology: an introduction. 7 th ed. W.B. Saunders, Philadelphia.

Wells J.W., Darling D., Farzaneh F. \& Galea-Lauri J. 2005. Influence of interleukin- 4 on the phenotype and function of bone marrow-derived murine dendritic cells generated under serum-free conditions. Scan. J. Immunol. 61(3):251-259.<https://dx.doi.org/10.1111/j.1365-3083.2005.01556.x> $<$ PMid:15787742>

Williams L.D., Burdock G.A., Jiménez G. \& Castillo M. 2009. Literature review on the safety of Toyocerin ${ }^{\circledR}$, a non-toxigenic and non-pathogenic Bacillus cereus var. Toyoi preparation. Regul. Toxicol. Pharmacol. 55(2):236-246. <https://dx.doi.org/10.1016/j.yrtph.2009.07.009> <PMid:19631708> 